\title{
Roles and Regulation of Voltage-gated Calcium Channels in Arrhythmias
}

\author{
JARED KUSHNER, $\mathrm{MD},{ }^{1}$ XAVIER FERRER, $\mathrm{BS}^{1}{ }^{1}$ and STEVEN O. MARX, $\mathrm{MD}^{1}$ \\ ${ }^{1}$ Division of Cardiology, Department of Medicine, Vagelos College of Physicians and Surgeons, Columbia University, \\ New York, NY, USA
}

\begin{abstract}
Calcium flowing through voltage-dependent calcium channels into cardiomyocytes mediates excitation-contraction coupling, controls action-potential duration and automaticity in nodal cells, and regulates gene expression. Proper surface targeting and basal and hormonal regulation of calcium channels are vital for normal cardiac physiology. In this review, we discuss the roles of voltage-gated calcium channels in the heart and the mechanisms by which these channels are regulated by physiological signaling pathways in health and disease.
\end{abstract}

KEYWORDS. Arrhythmias, calcium, calcium channels, heart.
ISSN 2156-3977 (print) ISSN 2156-3993 (online) CC BY 4.0 license

C) 2019 Innovations in Cardiac Rhythm Management

\section{Introduction}

In the heart, calcium $\left(\mathrm{Ca}^{2+}\right)$ entry through the voltage-gated $\mathrm{Ca}^{2+}$ channel initiates muscle excitation-contraction coupling. The influx of $\mathrm{Ca}^{2+}$ also contributes to the plateau phase of the action potential, pacemaker activity in nodal cells, and the modulation of critical cellular processes including metabolism and gene expression. Thus, $\mathrm{a} \mathrm{Ca}^{2+}$ influx via voltage-gated $\mathrm{Ca}^{2+}$ channels in the heart links membrane depolarization to cellular functions. In this review, we will discuss mechanisms of $\mathrm{Ca}^{2+}$ handling in the heart and how dysfunctions of voltage-gated $\mathrm{Ca}^{2+}$ channels can lead to arrhythmias. $\mathrm{Ca}^{2+}$ channels are modulated by voltage, $\mathrm{Ca}^{2+}$, posttranslational modifications, and protein-protein interactions, which will also be reviewed. Finally, we will discuss existing pharmacological therapies that target voltage-gated $\mathrm{Ca}^{2+}$ channels.

The authors report no conflicts of interest for the published content. This work was supported by National Institutes of Health research grant nos. R01 HL113136 and R01 HL121253. Additionally, Dr. Kushner was supported by the National Institutes of Health research grant no. T32 HL007343 and the Glorney-Raisbeck Fellowship and Junior Faculty Award from the New York Academy of Medicine, while Mr. Ferrer was supported by the National Institutes of Health research grant no. 5T35HL007616-38.

Manuscript received September 12, 2018. Final version accepted March 4, 2019.

Address correspondence to: Steven O. Marx, MD, 622 West 168th Street, PH-3 Center, New York, NY 10032, USA.

Email: sm460@cumc.columbia.edu.

\section{Structure and cellular electrophysiological function}

Six classes of voltage-gated $\mathrm{Ca}^{2+}$ channels exist that can be classified by membrane voltage activation (low versus high), susceptibility to pharmacologic antagonists, and rate of inactivation (Table 1); these include the T-, L-, $\mathrm{N}-$, P-, Q-, and R-type channels. Of these, only long-lasting (L)- and transient (T)-type $\mathrm{Ca}^{2+}$ channels are expressed in cardiomyocytes. ${ }^{1,2}$ In $\mathrm{Ca}^{2+}$ channel nomenclature, the chemical symbol of calcium, $\mathrm{Ca}$, is followed by a subscript " $\mathrm{V}$," denoting voltage as the primary regulator, and two numerical identifiers corresponding to the $\alpha_{1}$ subunit gene subfamily and the order of discovery within that subfamily, respectively. ${ }^{3,4} \mathrm{Ca}_{\mathrm{v}} 1.1, \mathrm{Ca}_{\mathrm{V}} 1.2, \mathrm{Ca}_{\mathrm{v}} 1.3$, and $\mathrm{Ca}_{\mathrm{v}} 1.4$ exhibit relatively long-lasting currents and are referred to as L-type $\mathrm{Ca}^{2+}$ channels. $\mathrm{Ca}_{\mathrm{v}} 3.1, \mathrm{Ca}_{\mathrm{v}} 3.2$, and $\mathrm{Ca}_{\mathrm{V}} 3.3$, which are T-type $\mathrm{Ca}^{2+}$ channels, exhibit transient $\mathrm{Ca}^{2+}$ currents and are activated at more negative potentials relative to L-type $\mathrm{Ca}^{2+}$ channels (Table 1).

Voltage-gated $\mathrm{Ca}^{2+}$ channels are composed of the pore-forming $\alpha_{1}$ subunit and several auxiliary subunits including $\beta$ and $\alpha_{2} \delta$ (Figure 1). Four homologous domains, each with six transmembrane helices and a pore loop between S5 and S6 forming the $\alpha_{1}$ subunit. Alternating, positively charged arginine or lysine residues at every third or fourth position in $\mathrm{S} 4$ of each domain impart voltage sensitivity. ${ }^{5}$ The $\alpha_{1}$ subunit contains binding sites for most regulators and drugs, whereas the $\beta, \alpha_{2} \delta$, and $\gamma$ 
Table 1: Properties of Voltage-gated $\mathrm{Ca}^{2+} \mathrm{Channels}^{64-68}$

\begin{tabular}{|c|c|c|c|c|c|}
\hline Isoform & Type & Gene & Localization & Antagonist & $\begin{array}{l}\text { Activation } \\
\text { Threshold }\end{array}$ \\
\hline $\mathrm{Ca}_{\mathrm{v}} 1.1$ & $\mathrm{~L}$ & CACNA1S & Skeletal muscle & DHP, PLZ, BNZ & $\sim-20 \mathrm{mV}$ \\
\hline $\mathrm{Ca}_{\mathrm{v}} 1.2$ & $L$ & CACNA1C & $\begin{array}{l}\text { Heart, nervous system, smooth } \\
\text { muscle, adrenal gland, pancreas, } \\
\text { kidney, cochlea }\end{array}$ & DHP, PLZ, BNZ & $\sim-20 \mathrm{mV}$ \\
\hline $\mathrm{Ca}_{\mathrm{v}} 1.3$ & L & CACNA1D & $\begin{array}{l}\text { Heart, nervous system, kidney, } \\
\text { adrenal gland, pancreas, lung, } \\
\text { testis, cochlea }\end{array}$ & DHP, PLZ, BNZ & $\sim-40 \mathrm{mV}$ \\
\hline $\mathrm{Ca}_{\mathrm{v}} 1.4$ & $\mathrm{~L}$ & CACNA1F & Retina & Unknown & $\sim-40 \mathrm{mV}$ \\
\hline $\mathrm{Ca}_{\mathrm{v}} 2.1$ & $P / Q$ & CACNA1A & $\begin{array}{l}\text { Nervous system, smooth muscle, } \\
\text { pancreas, cochlea }\end{array}$ & $\omega$-agatoxin IVA & \\
\hline $\mathrm{Ca}_{\mathrm{v}} 2.2$ & $\mathrm{~N}$ & CACNA1B & Nervous system, pancreas & $\omega$-conotoxin GVIA & $\sim-35 \mathrm{mV}$ \\
\hline $\mathrm{Ca}_{\mathrm{v}} 2.3$ & $R$ & CACNA1E & $\begin{array}{l}\text { Nervous system, heart, cochlea, } \\
\text { pancreas, lung }\end{array}$ & $\mathrm{SNX}-482, \mathrm{~Pb}^{2+}$ & $\sim-30 \mathrm{mV}$ \\
\hline $\mathrm{Ca}_{\mathrm{v}} 3.1$ & $T$ & CACNA1G & $\begin{array}{l}\text { Heart, nervous system, pancreas, } \\
\text { smooth muscle, kidney }\end{array}$ & $\begin{array}{l}\text { Mibefradil, } \\
\text { kurtoxin, } \mathrm{Ni}^{2+}\end{array}$ & $\sim-60 \mathrm{mV}$ \\
\hline $\mathrm{Ca}_{\mathrm{v}} 3.2$ & $T$ & CACNA1H & $\begin{array}{l}\text { Heart, nervous system, smooth } \\
\text { muscle, kidney }\end{array}$ & $\begin{array}{l}\text { Mibefradil, } \\
\text { kurtoxin, } \mathrm{Ni}^{2+}\end{array}$ & $\sim-60 \mathrm{mV}$ \\
\hline $\mathrm{Ca}_{\mathrm{v}} 3.3$ & $T$ & CACNA1I & Nervous system & $\begin{array}{l}\text { Mibefradil, } \\
\text { kurtoxin, } \mathrm{Ni}^{2+}\end{array}$ & $\sim-70 \mathrm{mV}$ \\
\hline
\end{tabular}

BNZ: benzothiazepines; DHP: dihydropyridines; PLK: phenylalkylamines.

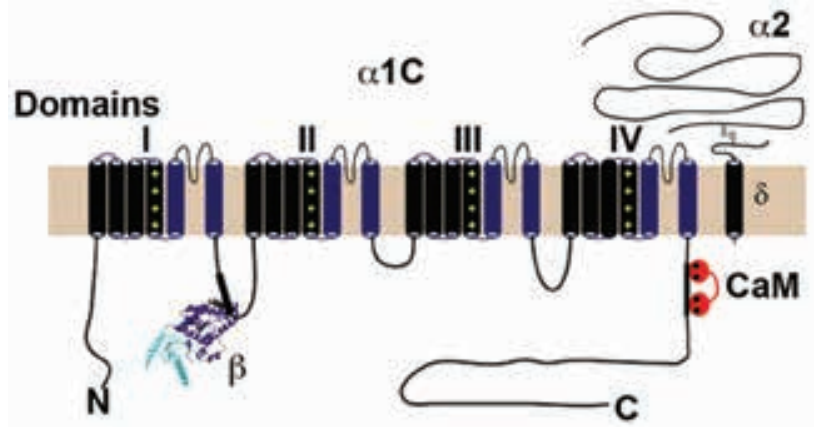

Figure 1: Schematic of cardiac $\alpha_{1 c}, \beta$, and $\alpha_{2}$ subunit topology. The $\beta$ subunit binds to the $\alpha$-interaction domain in the I-II loop of the $\alpha_{1 C}$ subunit. CaM binds to the C-terminus of $\alpha_{1 c}$.

subunits contribute to trafficking, anchoring, and regulatory functions. The pore region contains binding sites for all major L-type $\mathrm{Ca}^{2+}$ channel-blocking agents including dihydropyridines, phenylalkylamines, and benzothiazepines (Table 1). ${ }^{6}$

There are four $\beta$-subunit genes $\left(\mathrm{Ca}_{\mathrm{v}} \beta_{1-4}\right)$. The $\beta_{2}$ subunit is the predominantly expressed isoform in the adult heart. In all of the different $\beta$ subunits, the guanylate kinase (GK) and Src-homology 3 (SH3) domains are very similar, whereas the $\mathrm{N}$-termini (variable region 1 ), the linker between SH3 and GK (variable region 2), and the C-termini (variable region 3) are quite different. ${ }^{7-9}$ All $\beta$ subunits interact with the pore-forming $\alpha$ subunit via the intracellular loop between transmembrane domains I and II (Figure 1). In a cell-specific manner, $\beta$ subunits can increase trafficking of the channel to the plasma membrane and modulate both activation and inactivation. In mice, global or cardiac-specific deletion of the Cacnb2 gene leads to abnormal heart development and embryonic death. ${ }^{10}$ Conditional deletion of the $\beta_{2}$ subunit in adult mouse cardiomyocytes causes a $96 \%$ or so reduction in $\beta_{2}$ protein expression, but surprisingly only a $29 \%$ reduction in $\mathrm{Ca}^{2+}$ current, with no obvious cardiac impairment, ${ }^{11}$ implying that, in adult hearts, the $\beta_{2}$ expression may be expendable. However, interpretation of this result is ambiguous, as it is complicated by the remnant $(\sim 4 \%)$ $\beta_{2}$ expression as well as the presence of other $\mathrm{Ca}_{\mathrm{v}} \beta$ isoforms expressed in adult cardiomyocytes. ${ }^{9}$ Moreover, a contrasting viewpoint was provided by a study in which short hairpin RNA-mediated knockdown of $\beta_{2}$ in adult rat myocytes substantially diminished $\mathrm{Ca}^{2+}$ current. ${ }^{12}$

To definitively address the controversies regarding the role of $\beta$ subunits in mediating the trafficking and regulation of $\mathrm{Ca}^{2+}$ channels in the heart, we created transgenic mice lines with three mutations in the $\alpha$-interaction domain in the I-II loop of the $\alpha_{1 C}$ subunit, which renders the pore-forming $\alpha_{1 C}$ subunit incapable of binding $\beta$ subunits. With this new model, we definitively demonstrate in vivo that the $\beta$ subunit binding to $\alpha_{1 C}$ is not required for trafficking and that the basal function of $\beta$-less $\mathrm{Ca}^{+2}$ channels is only minimally altered. ${ }^{13}$

The $\alpha_{2} \delta$ subunit is a $175-\mathrm{kDa}$ single transmembrane protein encoded by four genes (Cacna2d1, Cacna2d2, Cacna2d3, and Cacna2d4) with multiple splice variants. Although the messenger RNAs of $\alpha_{2} \delta 1$ through $3^{14}$ have been identified in human myocardium, only $\alpha_{2} \delta-1$ is known to bind with $\mathrm{Ca}_{\mathrm{v}} 1.2$ (Figure 1). 
$\mathrm{Ca}^{2+}$ channels are inactivated in both voltage- and $\mathrm{Ca}^{2+}$-dependent manners, but $\mathrm{Ca}^{2+}$-dependent inactivation is the dominant mechanism. L-type $\mathrm{Ca}^{2+}$ channels associate with calmodulin (CaM) (Figure 1), which modulates both $\mathrm{Ca}^{2+}$-dependent inactivation and $\mathrm{Ca}^{2+}$-dependent facilitation, where $\mathrm{Ca}^{2+}$ currents increase after repetitive stimulation..$^{15}$ The importance of CaM regulation of L-type $\mathrm{Ca}^{2+}$ channels in the heart has been demonstrated by overexpressing in adult cardiac myocytes a mutated $\mathrm{CaM}$ protein that cannot bind $\mathrm{Ca}^{2+}$, leading to very long action potentials because of the loss of $\mathrm{Ca}^{2+}$-dependent inactivation. ${ }^{16}$ Although $\mathrm{Ca}^{2+}$ entry via the $\mathrm{Ca}^{2+}$ channel can contribute to $\mathrm{Ca}^{2+}$-dependent inactivation, remarkably, it is specifically the $\mathrm{Ca}^{2+}$ released from the sarcoplasmic reticulum via the ryanodine receptors that is the primary determinant of $\mathrm{Ca}^{2+}$-dependent inactivation.

\section{Roles of L- and T-type calcium channels in the heart}

Understanding the regulation of myocyte $\mathrm{Ca}^{2+}$ regulation is essential to understanding cardiac arrhythmogenesis. $\mathrm{Ca}_{\mathrm{v}} 1.2$ is situated on the transverse tubules in close proximity with ryanodine receptors (RyR2), which are intracellular $\mathrm{Ca}^{2+}$ release channels located on the sarcoplasmic reticulum. $\mathrm{Ca}^{2+}$ entry through the L-type $\mathrm{Ca}^{2+}$ channels triggers ryanodine receptors to release $\mathrm{Ca}^{2+}$ from the sarcoplasmic reticulum into the cytoplasm as part of a process known as $\mathrm{Ca}^{2+}$-induced $\mathrm{Ca}^{2+}$ release (Figure 2). ${ }^{17} \mathrm{Ca}^{2+}$ influx via $\mathrm{Ca}^{2+}$-channel current and

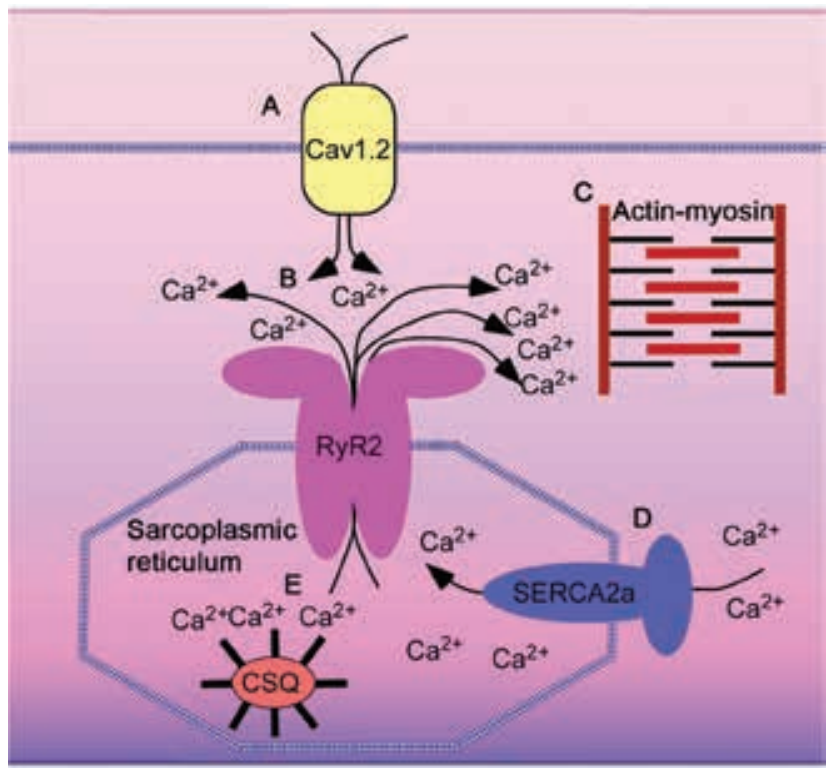

Figure 2: Excitation-contraction coupling in cardiomyocytes. $\mathrm{A}$ and $\mathrm{B}: \mathrm{Ca}^{2+}$ entry via $\mathrm{Ca}_{\mathrm{v}} 1.2$ causes $\mathrm{Ca}^{2+}$-induced $\mathrm{Ca}^{2+}$ release via the ryanodine receptor (RyR2). C: $\mathrm{Ca}^{2+}$ binds to troponin $\mathrm{C}$, inducing cross-bridging between actin and myosin. $\mathrm{D}: \mathrm{Ca}^{2+}$ is pumped back into the sarcoplasmic reticulum via SERCA2a. The same amount of $\mathrm{Ca}^{2+}$ that enters the cell via $\mathrm{Ca}_{v} 1.2$ is pumped out of the cells via the $\mathrm{Na}^{+}-\mathrm{Ca}^{2+}-$ exchanger and $\mathrm{Ca}^{2+}$ pumps (not shown). E: $\mathrm{Ca}^{2+}$ binds to CSQ in the sarcoplasmic reticulum.
$\mathrm{Ca}^{2+}$ release via ryanodine receptors are required for myofilament activation (Figure 2). $\mathrm{Ca}^{2+}$ binds to troponin $\mathrm{C}$ on the thin filament, allowing the myosin heads to bind to actin. ${ }^{18}$ The strength of contraction is proportional to the concentration of $\mathrm{Ca}^{2+}$ surrounding the myofilaments. In order to fully relax myocytes in preparation for the next heartbeat, the amount of $\mathrm{Ca}^{2+}$ that enters the cardiac cell during steady state must equal the amount of $\mathrm{Ca}^{2+}$ that leaves the cell. ${ }^{18}$ The reduction in cellular $\mathrm{Ca}^{2+}$ concentration is driven by $\mathrm{Ca}^{2+}$ transport via the sarcoplasmic reticulum $\mathrm{Ca}^{2+}$-adenosine triphosphate pump (SERCA) and the sarcolemmal $\mathrm{Na}^{+} / \mathrm{Ca}^{2+}$ exchanger (Figure 2). During the action potential, voltage-gated $\mathrm{Ca}^{2+}$ channels open and allow $\mathrm{Ca}^{2+}$ to flow down its electrochemical gradient, causing the plateau phase (phase 2) of the action potential (Figure 3). Outside of the t-tubules, L-type $\mathrm{Ca}^{2+}$ channels are also localized to caveolae-membrane invaginations important for concentrating proteins that are essential for the coordinating responses to extracellular signals-wherein $\mathrm{Ca}^{2+}$ influx can control signal transduction pathways. In ventricular myocytes, the $\mathrm{Ca}^{2+}$ current is mediated nearly entirely by the L-type $\mathrm{Ca}^{2+}$ channel, $\mathrm{Ca}_{\mathrm{V}} 1.2$. In atrial and especially pacemaker cells, the L-type $\mathrm{Ca}^{2+}$ channel isoform $\mathrm{Ca}_{\mathrm{v}} 1.3$, which activates at more negative potentials, contributes to the late phase 4 depolarization that underlies these cells' automaticity (Table 1).

In contrast to L-type $\mathrm{Ca}^{2+}$ current, T-type $\mathrm{Ca}^{2+}$ current has little effect on cardiomyocyte excitation-contraction coupling in the heart. ${ }^{19}$ The high density of T-type $\mathrm{Ca}^{2+}$ current in nodal cells ${ }^{20}$ and embryonic cardiomyocytes ${ }^{21}$ however, is consistent with their putative role in pacemaker function. T-type $\mathrm{Ca}^{2+}$ channels contribute to triggered or pacemaker activity because they activate at even more negative potentials than L-type $\mathrm{Ca}^{2+}$ channels (Table 1). However, they produce smaller peak $\mathrm{Ca}^{2+}$ currents and cannot substitute for L-type $\mathrm{Ca}^{2+}$ channels because T-type $\mathrm{Ca}^{2+}$ channels do not target to the sarcolemmal-sarcoplasmic reticulum junctions and therefore cannot initiate sarcoplasmic $\mathrm{Ca}^{2+}$ release.

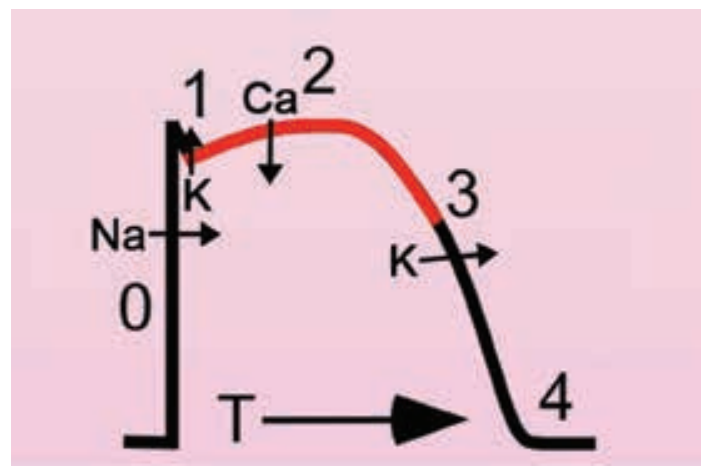

Figure 3: Diagram of cardiac action potential showing phases $0,1,2,3$, and 4 . During phase $0, \mathrm{Na}^{+}$influx initiates the cardiac action potential. During phase $2, \mathrm{Ca}^{2+}$ entry via the L-type $\mathrm{Ca}^{2+}$ channel initiates excitation-contraction coupling. 


\section{Pharmacology}

There are three main chemical classes of organic $\mathrm{Ca}^{2+}$ channel drugs, specifically dihydropyridine (prototype: nifedipine), phenylalkylamines (prototype: verapamil), and benzothiazepines (prototype: diltiazem). All three classes of drugs bind within a single overlapping region close to the pore and the proposed activation gate. ${ }^{22,23}$ These drugs interfere with the voltage-dependent cycling of the channel. ${ }^{24-26}$ The uncharged dihydropyridines, which possess higher affinity for the inactivated channel conformation (voltage- or use-dependent block), induce and stabilize inactivated channel states. ${ }^{24-27}$ Smooth-muscle $\mathrm{Ca}_{\mathrm{V}} 1.2$ channels are more sensitive to inhibition by dihydropyridines than cardiac $\mathrm{Ca}_{\mathrm{V}} 1.2$ channels because the inactivated channel states are favored in arterial smooth muscle cells due to the relatively depolarized membrane potential of these cells and the splice variant of the S6 segment of domain 1, which is specifically expressed in this tissue. ${ }^{25,28,29}$

$\mathrm{Ca}_{\mathrm{V}} 1.3$ is less sensitive to dihydropyridines than $\mathrm{Ca}_{\mathrm{V}} 1.2$ is. Phenylalkylamines and benzothiazepines bind to the open and inactivated states with high affinity and stabilize the inactivated channel states, slowing recovery from inactivation, leading to use-dependent inhibition. ${ }^{30,31}$ Therefore, inhibition increases with higher heart rates, rationalizing the use of verapamil for tachyarrhythmias. Whereas verapamil and diltiazem always reduce inward $\mathrm{Ca}^{2+}$ currents, some dihydropyridines, such as (-)-BAY-K-8644 and (+)-SDS-202-791, are gating modifiers that act as agonists, increasing current amplitudes, tail currents, and single-channel open probability. ${ }^{27}$

\section{Disease states/channelopathies}

Prolongation of the action-potential duration increases the loading of $\mathrm{Ca}^{2+}$ within the cells due to prolonged $\mathrm{Ca}^{2+}$ entry and a reduced diastolic interval for $\mathrm{Ca}^{2+}$ efflux. Moreover, some L-type $\mathrm{Ca}^{2+}$ channels become available again during the prolonged action-potential duration, and the channels reactivate, creating an inward $\mathrm{Ca}^{2+}$ influx, which can cause early afterdepolarizations. ${ }^{32}$ Increased L-type $\mathrm{Ca}^{2+}$ current also contributes to delayed afterdepolarizations and $\mathrm{Ca}^{2+}$-evoked arrhythmias, which occur after repolarization is complete and are exacerbated by sarcoplasmic reticulum $\mathrm{Ca}^{2+}$ overload. Mutations in L-type $\mathrm{Ca}^{2+}$ channels have been associated with inherited arrhythmia syndromes.

Timothy syndrome, a multisystem disorder characterized by a prolonged QT interval and syndactyly as well as variably penetrant phenotypes of autism spectrum disorders, craniofacial abnormalities, and hypoglycemia, ${ }^{33}$ is caused by the loss of voltage-dependent inactivation. ${ }^{33}$ The heterogeneous phenotype reflects the distribution of expression in the heart, brain, kidney, gastrointestinal tract, immune system, smooth muscle, testis, and pituitary and adrenal glands (Table 1). The diagnosis is typically made within the first few days of life due to fetal bradycardia caused by functional 2:1 atrioventricular block. When completely expressed, Timothy syndrome is typically lethal within the first years of life. Repolarization is markedly prolonged in most patients with Timothy syndrome, with the corrected QT interval often exceeding $550 \mathrm{~ms}$ to $600 \mathrm{~ms}^{34}$ Congenital cardiac defects are present in $60 \%$ of patients and cardiac hypertrophy and ventricular dilatation have been reported to occur in $50 \%$ of patients. ${ }^{33-35}$ Ventricular arrhythmias are the most frequent cause of death. There are no systematic studies assessing the best therapeutic strategy for patients with Timothy syndrome published to date. The available evidence supports the use of $\beta$-blockers and late $\mathrm{Na}^{+}$channel blockers, and the use of implantable cardioverter-defibrillators for primary prevention is also reasonable. ${ }^{36-39}$ Close monitoring of glucose levels is essential, however, since $\beta$-blockers can mask the hypoglycemia caused by Timothy syndrome.

Mutations in 19 genes have been identified as associated with the Brugada phenotype, causing either a decrease in inward $\mathrm{Na}^{+}$or $\mathrm{Ca}^{2+}$ currents or an increase in outward $\mathrm{K}^{+}$currents. ${ }^{40}$ The resultant outward shift in the balance of currents active during phases 1 and 2 of the epicardial action potential allows for the already prominent transient outward $\mathrm{K}^{+}$current to augment phase 1 repolarization. If the membrane potential is repolarized too much, L-type $\mathrm{Ca}^{2+}$ channels fail to activate, leading to a reduction in the action potential plateau predominantly in the right ventricular subepicardial cells in which the transient outward $\mathrm{K}^{+}$current is most prominent. Loss-offunction mutations in the pore-forming $\alpha_{1 C}$ subunit, the $\beta_{2 b}$ subunit, and the $\alpha_{2} \delta_{1}$ subunit have also been linked to Brugada, early repolarization, and short-QT syndromes. ${ }^{41-44}$ Agents that augment L-type $\mathrm{Ca}^{2+}$ currents, such as $\beta$-adrenergic agonists, have been shown to have therapeutic efficacy in Brugada syndrome. ${ }^{40,45-47}$

Short-QT syndrome ${ }^{48}$ is one of the rarest inheritable cardiac channelopathies, characterized by an accelerated cardiac repolarization. It is an autosomal-dominant disease with five identified causative genes, including three that encode for $\mathrm{K}^{+}$channels (KCNH2, KCNQ1, and KCNJ2) and two that encode for subunits of the L-type $\mathrm{Ca}^{2+}$ channels (CACNA1C and CACNB2). ${ }^{49-51}$ Mutations in the $\mathrm{Ca}_{\mathrm{V}} 1.2$ genes $C A C N A 1 C$ and $C A C N B 2 b$ have also been associated with both idiopathic ventricular fibrillation and early repolarization syndrome. ${ }^{43}$

A mutation in $C A C N A 1 D$, which encodes $\mathrm{Ca}_{\mathrm{V}} 1.3$, was identified in a Pakistani family with pronounced bradycardia resulting from nonconducting $\mathrm{Ca}_{\mathrm{V}} 1.3$ channels. ${ }^{52}$ A loss of $\mathrm{Ca}_{\mathrm{V}} 1.3$ reduces automaticity in pacemaker cells. Taken together, mutations of the core subunits of the L-type $\mathrm{Ca}^{2+}$ channels cause various cardiac syndromes and arrhythmias, including long-QT syndrome, Timothy syndrome, Brugada syndrome, short-QT syndrome, early repolarization, and bradycardia.

\section{Posttranslational regulation of calcium channels}

Epinephrine and norepinephrine bind to $\beta$-adrenergic receptors in cardiomyocytes, the activation of which 
augments inotropy, lusitropy, and chronotropy. ${ }^{18}$ The activity of both protein kinase A (PKA) and $\mathrm{Ca}^{2+}-\mathrm{CaM}$ activated protein kinase (CaMKII) increases with $\beta$-adrenergic stimulation, and both kinases provoke a rise in $\mathrm{Ca}_{\mathrm{v}} 1.2$ activity. The heightened activation of $\mathrm{Ca}_{\mathrm{v}} 1.2$, in turn, triggers increased contractility and $\mathrm{Ca}^{2+}$-responsive signaling pathways, which contribute to the pathogenesis of heart failure and hypertrophy. ${ }^{53,54}$

The molecular mechanism responsible for the $\beta$-adrenergic regulation of cardiac $\mathrm{Ca}_{\mathrm{v}} 1.2$ has remained a mystery. Experiments expressing recombinant $\mathrm{Ca}_{\mathrm{V}} 1.2$ in cultured cells (which have been, up until recently, the primary means of studying $\mathrm{Ca}_{\mathrm{v}} 1.2$ regulation) have not given a clear answer, since $\beta$-adrenergic regulation is not reliably reconstituted in standard cell lines and cardiomyocytes are irrevocably altered when cultured ex vivo. ${ }^{55,56}$ Thus, studies are required in native systems. The failure thus far to identify any single site as essential for $\beta$-adrenergic modulation led us to propose an alternative hypothesis: that a combination of phosphorylation sites in $\alpha_{1 C}$ is required for $\beta$-adrenergic stimulation of $\mathrm{Ca}_{\mathrm{v}} 1$.2. Since $\beta$-adrenergic regulation of cardiac $\mathrm{Ca}_{\mathrm{V}} 1.2$ is conserved in vertebrates, we identified conserved PKA consensus sequences in the $\alpha_{1 c}$ subunit of five species: mouse, rat, rabbit, guinea pig, and human. We then generated $\alpha_{1 c}$ transgenic mice in which we replaced the 17 conserved consensus PKA phosphorylation sites that were not previously studied and the five conserved PKA/CaMKII phosphorylation sites that were known to be nonessential. ${ }^{57-60}$ Surprisingly, we found that none of these PKA consensus phosphorylation sites were necessary. ${ }^{61}$ Instead, we found that $\beta$-subunit binding to the $\mathrm{Ca}_{\mathrm{v}} 1.2 \alpha_{1 \mathrm{C}}$ subunit, but not PKA phosphorylation of $\beta$, is absolutely essential for the augmentation of $\mathrm{Ca}^{2+}$ current and cardiac contractile response to $\beta$-adrenergic-related PKA stimulation..$^{13}$ These findings identify the key regulatory mechanisms impacting $\beta$-adrenergic regulation of $\mathrm{Ca}^{2+}$ influx and contractility in the heart.

$\mathrm{Ca}_{\mathrm{V}} 1.2$ is also a major target of CaMKII, and the resulting $\mathrm{Ca}^{2+}$-dependent facilitation of $\mathrm{Ca}_{\mathrm{v}} 1.2$ current, observed as a positive "staircase" of $\mathrm{Ca}^{2+}$ current in which current amplitude increases and inactivation slows over a series of repetitive pulses, is a powerful feed-forward effect on $\mathrm{Ca}^{2+}$ signaling in the heart. It is likely that phosphorylation of both $\alpha_{1 C}$ and $\beta_{2}$ subunits are required for CaMKII potentiation. ${ }^{62,63}$

\section{Conclusions}

$\mathrm{Ca}^{2+}$ channels are absolutely essential regulators of intracellular $\mathrm{Ca}^{2+}$, automaticity, and contractility. The channels are regulated by a macromolecular complex consisting of core subunits and kinases, phosphatases, cytoskeletal proteins, and adaptor proteins. The dysfunction of the channels, caused by either genetic or acquired factors, is associated with heart failure, hypertrophy, or arrhythmias. Future ideal goals include providing a greater molecular understanding of the mechanisms underlying $\mathrm{Ca}^{2+}$ channel subcellular targeting, function, and modulation in cardiomyocytes in health and disease.

\section{References}

1. Bean BP. Two kinds of calcium channels in canine atrial cells. Differences in kinetics, selectivity, and pharmacology. J Gen Physiol. 1985;86(1):1-30.

2. Nilius B, Hess P, Lansman JB, Tsien RW. A novel type of cardiac calcium channel in ventricular cells. Nature. 1985;316(6027):443-446.

3. Catterall WA, Striessnig J, Snutch TP, Perez-Reyes E. International Union of Pharmacology. XL. Compendium of voltage-gated ion channels: calcium channels. Pharmacol Rev. 2003;55(4):579-581.

4. Ertel EA, Campbell KP, Harpold MM, et al. Nomenclature of voltage-gated calcium channels. Neuron. 2000;25(3): 533-535.

5. Catterall WA. Structure and regulation of voltage-gated Ca2+ channels. Annu Rev Cell Dev Biol. 2000.16:521-555.

6. Striessnig J. Pharmacology, structure and function of cardiac L-type $\mathrm{Ca}(2+)$ channels. Cell Physiol Biochem. 1999;9(4-5):242-269.

7. De Waard M, Pragnell M, Campbell KP. Ca2+ channel regulation by a conserved $\beta$ subunit domain. Neuron. 1994;13(2):495-503.

8. Birnbaumer L, Qin N, Olcese R, et al. Structures and functions of calcium channel beta subunits. J Bioenerg Biomembr. 1998;30(4):357-375.

9. Buraei Z, Yang J. The $\beta$ subunit of voltage-gated Ca2+ channels. Physiol Rev. 2010;90(4):1461-1506.

10. Weissgerber $\mathrm{P}$, Held $\mathrm{B}, \mathrm{Bloch} \mathrm{W}$, et al. Reduced cardiac L-type Ca2+ current in $\mathrm{Ca}(\mathrm{V})$ beta2-/- embryos impairs cardiac development and contraction with secondary defects in vascular maturation. Circ Res. 2006;99(7):749-757.

11. Meissner $M$, Weissgerber $P$, Londoño JE, et al. Moderate calcium channel dysfunction in adult mice with inducible cardiomyocyte-specific excision of the cacnb2 gene. J Biol Chem. 2011;286(18):15875-15882.

12. Cingolani E, Ramirez Correa GA, Kizana E, Murata M, Cho HC, Marbán E. Gene therapy to inhibit the calcium channel beta subunit: physiological consequences and pathophysiological effects in models of cardiac hypertrophy. Circ Res. 2007;101(2):166-175.

13. Yang L, Katchman A, Kushner J, et al. Cardiac CaV1.2 channels require beta subunits for beta-adrenergic-mediated modulation but not trafficking. J Clin Invest. 2019;129(2):647-658.

14. Gong HC, Hang J, Kohler W, Li L, Su TZ. Tissue-specific expression and gabapentin-binding properties of calcium channel alpha2delta subunit subtypes. J Membr Biol. 2001;184(1):35-43.

15. Halling DB, Aracena-Parks P, and Hamilton SL. Regulation of voltage-gated $\mathrm{Ca} 2+$ channels by calmodulin. Sci STKE. 2005;2005(315):re15.

16. Alseikhan BA, DeMaria CD, Colecraft HM, Yue DT. Engineered calmodulins reveal the unexpected eminence of Ca2+ channel inactivation in controlling heart excitation. Proc Natl Acad Sci USA. 2002;99(26):17185-17190.

17. Fabiato A, Fabiato F. Contractions induced by a calciumtriggered release of calcium from the sarcoplasmic reticulum of single skinned cardiac cells. J Physiol. 1975;249(3): 469-495.

18. Bers DM. Cardiac excitation-contraction coupling. Nature. 2002;415(6868):198-205.

19. Sipido KR, Carmeliet E, Van de Werf F. T-type Ca2+ current as a trigger for $\mathrm{Ca} 2+$ release from the sarcoplasmic reticulum in guinea-pig ventricular myocytes. J Physiol. 1998;508(Pt 2): 439-451. 
20. Hagiwara N, Irisawa H, Kameyama M. Contribution of two types of calcium currents to the pacemaker potentials of rabbit sino-atrial node cells. J Physiol. 1988;395:233-253.

21. Wetzel GT, Chen F, Klitzner TS. Ca2+ channel kinetics in acutely isolated fetal, neonatal, and adult rabbit cardiac myocytes. Circ Res. 1993;72(5):1065-1074.

22. Cheng RC, Tikhonov DB, Zhorov BS. Structural model for phenylalkylamine binding to L-type calcium channels. J Biol Chem. 2009;284(41):28332-28342.

23. Tikhonov DB, Zhorov BS. Structural model for dihydropyridine binding to L-type calcium channels. J Biol Chem. 2009;284(28):19006-19017.

24. Striessnig J, Ortner NJ, Pinggera A. Pharmacology of L-type calcium channels: novel drugs for old targets?. Curr Mol Pharmacol. 2015;8(2):110-122.

25. Bean BP, Sturek M, Puga A, Hermsmeyer K. Calcium channels in muscle cells isolated from rat mesenteric arteries: modulation by dihydropyridine drugs. Circ Res. 1986;59(2):229-235.

26. Berjukow $S$, Hering S. Voltage-dependent acceleration of $\mathrm{Ca}(\mathrm{v}) 1.2$ channel current decay by (+)- and (-)-isradipine. $\mathrm{Br}$ J Pharmacol. 2001;133(7):959-966.

27. Hamilton SL, Yatani A, Brush K, Schwartz A, Brown AM. A comparison between the binding and electrophysiological effects of dihydropyridines on cardiac membranes. Mol Pharmacol. 1987;31(3):221-231.

28. Fleischmann BK, Murray RK, Kotlikoff MI. Voltage window for sustained elevation of cytosolic calcium in smooth muscle cells. Proc Natl Acad Sci USA. 1994;91(25):11914-11918.

29. Welling A, Ludwig A, Zimmer S, Klugbauer N, Flockerzi V, Hofmann F. Alternatively spliced IS6 segments of the alpha $1 \mathrm{C}$ gene determine the tissue-specific dihydropyridine sensitivity of cardiac and vascular smooth muscle L-type Ca2+ channels. Circ Res. 1997;81(4):526-532.

30. Beyl S, Timin EN, Hohaus A, et al. Probing the architecture of an L-type calcium channel with a charged phenylalkylamine: evidence for a widely open pore and drug trapping. J Biol Chem. 2007;282(6):3864-38670.

31. Hering S, Aczél S, Kraus RL, Berjukow S, Striessnig J, Timin EN. Molecular mechanism of use-dependent calcium channel block by phenylalkylamines: role of inactivation. Proc Natl Acad Sci USA. 1997;94(24):13323-13328.

32. January CT, Riddle JM. Early afterdepolarizations: mechanism of induction and block. A role for L-type Ca2+ current. Circ Res. 1989;64(5):977-990.

33. Splawski I, Timothy KW, Decher N, et al. Severe arrhythmia disorder caused by cardiac L-type calcium channel mutations. Proc Natl Acad Sci USA. 2005;102(23):8089-8096; discussion 8086-8088.

34. Splawski I, Timothy KW, Sharpe LM, et al. Ca(V)1.2 calcium channel dysfunction causes a multisystem disorder including arrhythmia and autism. Cell. 2004;119(1):19-31.

35. Lo-A-Njoe SM, Wilde AA, van Erven L, Blom NA. Syndactyly and long QT syndrome (CaV1.2 missense mutation G406R) is associated with hypertrophic cardiomyopathy. Heart Rhythm. 2005;2(12):1365-1368.

36. Priori SG, Napolitano C, Schwartz PJ, et al. Association of long QT syndrome loci and cardiac events among patients treated with beta-blockers. JAMA. 2004;292(11):1341-1344.

37. Gao Y, Xue X, Hu D, et al. Inhibition of late sodium current by mexiletine: a novel pharmotherapeutical approach in Timothy syndrome. Circ Arrhythm Electrophysiol. 2013;6(3):614-622.

38. Shah DP, Baez-Escudero JL, Weisberg IL, Beshai JF, Burke MC. Ranolazine safely decreases ventricular and atrial fibrillation in Timothy syndrome (LQT8). Pacing Clin Electrophysiol. 2012;35(3):e62-e64.

39. Sicouri S, Timothy KW, Zygmunt AC, et al. Cellular basis for the electrocardiographic and arrhythmic manifestations of Timothy syndrome: effects of ranolazine. Heart Rhythm. 2007;4(5):638-647.

40. Antzelevitch C, Patocskai B. Brugada syndrome: clinical, genetic, molecular, cellular, and ionic aspects. Curr Probl Cardiol. 2016;41(1):7-57.

41. Betzenhauser MJ, Pitt GS, Antzelevitch C. Calcium channel mutations in cardiac arrhythmia syndromes. Curr Mol Pharmacol. 2015;8(2):133-142.

42. Antzelevitch C, Pollevick GD, Cordeiro JM, et al. Loss-offunction mutations in the cardiac calcium channel underlie a new clinical entity characterized by ST-segment elevation, short QT intervals, and sudden cardiac death. Circulation. 2007;115(4):442-449.

43. Burashnikov E, Pfeiffer R, Barajas-Martinez $H$, et al. Mutations in the cardiac L-type calcium channel associated with inherited J-wave syndromes and sudden cardiac death. Heart Rhythm. 2010;7(12):1872-1882.

44. Cordeiro JM, Marieb M, Pfeiffer R, Calloe K, Burashnikov E, Antzelevitch C. Accelerated inactivation of the L-type calcium current due to a mutation in CACNB2b underlies Brugada syndrome. J Mol Cell Cardiol. 2009;46(5):695-703.

45. Ohgo T, Okamura H, Noda $\mathrm{T}$, et al. Acute and chronic management in patients with Brugada syndrome associated with electrical storm of ventricular fibrillation. Heart Rhythm. 2007;4(6):695-700.

46. Tsuchiya T, Ashikaga K, Honda T, Arita M. Prevention of ventricular fibrillation by cilostazol, an oral phosphodiesterase inhibitor, in a patient with Brugada syndrome. I Cardiovasc Electrophysiol. 2002;13(7):698-701.

47. Maury P, Couderc P, Delay M, Boveda S, Brugada J. Electrical storm in Brugada syndrome successfully treated using isoprenaline. Europace. 2004;6(2):130-133.

48. Gussak I, Brugada P, Brugada J, et al. Idiopathic short QT interval: a new clinical syndrome? Cardiology. 2000;94(2):99-102.

49. Chen Y, Barajas-Martinez H, Zhu D, et al. Novel trigenic CACNA1C/DES/MYPN mutations in a family of hypertrophic cardiomyopathy with early repolarization and short QT syndrome. J Transl Med. 2017;15(1):78.

50. Templin C, Ghadri JR, Rougier JS, et al. Identification of a novelloss-of-function calcium channel gene mutation in short QT syndrome (SQTS6). Eur Heart J. 2011;32(9):1077-1088.

51. Zhang Q, Chen J, Qin Y, Wang J, Zhou L. Mutations in voltage-gated L-type calcium channel: implications in cardiac arrhythmia. Channels (Austin). 2018;12(1):201-218.

52. Baig SM, Koschak A, Lieb A, et al. Loss of $\mathrm{Ca}(\mathrm{v}) 1.3$ (CACNA1D) function in a human channelopathy with bradycardia and congenital deafness. Nat Neurosci. 2011;14(1):77-84.

53. Bodi I, Mikala G, Koch SE, Akhter SA, Schwartz A. The L-type calcium channel in the heart: the beat goes on. J Clin Invest. 2005;115(12):3306-3317.

54. Tandan S, Wang Y, Wang TT, et al. Physical and functional interaction between calcineurin and the cardiac L-type Ca2+ channel. Circ Res. 2009;105(1):51-60.

55. Subramanyam P, Chang DD, Fang K, Xie W, Marks AR, Colecraft HM. Manipulating L-type calcium channels in cardiomyocytes using split-intein protein transsplicing. Proc Natl Acad Sci USA. 2013;110(38):15461-15466.

56. Miriyala J, Nguyen T, Yue DT, Colecraft HM. Role of CaVbeta subunits, and lack of functional reserve, in protein 
kinase A modulation of cardiac CaV1.2 channels. Circ Res. 2008;102(7):e54-e64.

57. Brandmayr J, Poomvanicha M, Domes K, et al. Deletion of the C-terminal phosphorylation sites in the cardiac beta-subunit does not affect the basic beta-adrenergic response of the heart and the $\mathrm{Ca}(\mathrm{v}) 1.2$ channel. J Biol Chem. 2012;287(27):22584-25892.

58. De Jongh KS, Murphy BJ, Colvin AA, et al. Specific phosphorylation of a site in the full-length form of the alpha 1 subunit of the cardiac L-type calcium channel by adenosine 3',5'-cyclic monophosphate-dependent protein kinase. Biochemistry. 1996;35(32):10392-10402.

59. Ganesan AN, Maack C, Johns DC, Sidor A, O'Rourke B. Beta-adrenergic stimulation of L-type $\mathrm{Ca} 2+$ channels in cardiac myocytes requires the distal carboxyl terminus of alpha1C but not serine 1928. Circ Res. 2006;98(2):e11-e18.

60. Lemke T, Welling A, Christel CJ, et al. Unchanged beta-adrenergic stimulation of cardiac L-type calcium channels in $\mathrm{Ca}$ v 1.2 phosphorylation site S1928A mutant mice. J Biol Chem. 2008;283(50):34738-34744.

61. Katchman A, Yang L, Zakharov SI, et al. Proteolytic cleavage and PKA phosphorylation of alpha1C subunit are not required for adrenergic regulation of $\mathrm{CaV} 1.2$ in the heart. Proc Natl Acad Sci USA. 2017;114(34):9194-9199.
62. Blaich A, Welling A, Fischer S, et al. Facilitation of murine cardiac L-type $\mathrm{Ca}(\mathrm{v}) 1.2$ channel is modulated by calmodulin kinase II-dependent phosphorylation of S1512 and S1570. Proc Natl Acad Sci USA. 2010;107(22):10285-10289.

63. Koval OM, Guan X, Wu Y, et al. CaV1.2 beta-subunit coordinates CaMKII-triggered cardiomyocyte death and afterdepolarizations. Proc Natl Acad Sci USA. 2010;107(11):4996-5000.

64. Alexander SP, Benson HE, Faccenda E, et al. The Concise Guide to PHARMACOLOGY 2013/14: ion channels. Br J Pharmacol. 2013;170(8):1607-1651.

65. CatterallWA,Perez-ReyesE,Snutch TP,StriessnigJ.Voltage-gated calcium channels. 2015. Available at: https: / /www.guidetopharmacology.org/GRAC/FamilyDisplayForward?familyId=80. Accessed April 12, 2015.

66. Li L, Bischofberger J, Jonas P. Differential gating and recruitment of $\mathrm{P} / \mathrm{Q}-, \mathrm{N}-$, and $\mathrm{R}$-type $\mathrm{Ca} 2+$ channels in hippocampal mossy fiber boutons. J Neurosci. 2007;27(49): 13420-13429.

67. Monteil A, Chemin J, Bourinet E, et al. Molecular and functional properties of the human alpha(1G) subunit that forms T-type calcium channels. J Biol Chem. 2000;275(9): 6090-6100.

68. Zipes DP, Jalife J, Stevenson WG. Cardiac Electrophysiology: From Cell to Bedside. 7th ed. Philadelphia, PA: Elsevier; 2018. 